\title{
THEORETICAL ASPECTS OF THE INFLUENCE OF MOTIVATION ON INCREASING THE EFFICIENCY OF PHYSICAL EDUCATION
}

\author{
Nabijon Narzikulovich Norboev
}

Lecturer, Department Of Sports Management,Termez State University, Uzbekistan

\section{ABSTRACT}

A large role in maintaining and strengthening health, optimal body tone is played by rational motor activity, which for children and adolescents can be implemented at physical culture lessons in order to correctly form their motor skills and abilities, master the basic principles of improving physical qualities and educating the need for their implementation not only in physical education lessons, but also at home, in everyday life. Unfortunately, in recent years, students' interest in physical activity has been steadily declining. That is why this article substantiates the need to increase the motivational sphere among students for physical education.

KEYWORDS:- Theoretical aspects, physical education lesson, students, physical education teacher, motivation, interest in classes.

\section{INTRODUCTION}

With the development of society and modern technologies, the attitude towards physical culture is changing. In connection with the increase in the time that the younger generation spends in a sitting position for lessons in front of a computer monitor and TV, there is a growing need to motivate students to exercise during the school day, as well as in their free time. That is why the formation of motives for such activities is an important need of society, because systematic physical education contributes to the development of basic physical qualities, fostering will, courage, perseverance, have a positive effect on health promotion, increase mental performance and social adaptation [1, pp. 47-51].

Analysis of the development of pedagogical theory and practice shows that at all stages of the formation of vocational education, scientists searched for new approaches and criteria for motivating schoolchildren to learn, the formation of interest in physical activity.

\section{Methods}

The study of methods of physical education, in particular the formation of a positive interest in physical education of schoolchildren, has recently attracted special attention as teachers 
and scientists and is a promising direction of scientific research in the system of national education and upbringing [2, pp. 405-413].

The objective of the research is to summarize the data of scientific and methodological literature on the issue under study; to analyze the main directions of increasing schoolchildren's motivation for physical activity, to identify the main ways of developing interest in physical education.

\section{THE MAIN FINDINGS AND RESULTS}

An important component in the structure of teaching motional actions at physical culture lessons is the motivation of students to practice. It can be defined as a complex multi-level system of pathogens, including needs, motives, ideals, aspirations, attitudes, emotions, values, etc. A person's activity is mainly determined by the purpose of his activity. The specificity of human motivated activity is that it is always purposeful [3, pp. 64-74].

In a general sense, a motive is what stimulates a person to take a certain action. According to a number of scientists, the motives that are guided by teachers when teaching have a significant impact on the course of the learning process.

The motives may be different, but in all cases they must be positive. It is important for a teacher to know what motives and interests each of the students should have (for example, come to a specific lesson). For the most part, it is the motives that determine the future course of the entire learning process [4].

Interest is one of the main components of motivation. Interest is a conscious positive attitude towards something that prompts a person to be active in learning about the object of interest. Enthusiasm includes the idea of an object; a sense of satisfaction that evokes the object; attitude to volitional efforts, the influence of a pleasant or positive feeling on the will. For their part, interests are characterized by orientation (they distinguish material, spiritual, intellectual, social, cognitive, sports, professional interests) and selectivity (interest in sports games, in the profession of a physical education teacher) [5, pp. 1348-1354].

Spiritual interests develop most effectively when there is a possibility of their satisfaction. The main motives and driving forces of a social subject, group, class, and society appear in interest. It is by their presence and content that one can judge the comprehensive both physical and intellectual interest of the teacher $[6, \mathrm{pp}$. 381-383; 7].

Intellectual interests are knowledge of the subject and methodology, cultural outlook, understanding of children, the ability to communicate with them, the ability to maintain discipline, unite the team, organize individual and collective activities to form sustainable interests in physical exercises or motor games and, on their basis, foster a positive attitude towards physical culture and sports [8; 9, pp. 7379].

The formation of interest in the study of certain motor actions in physical culture lessons is as follows: verbal forms of influence on the consciousness of students should be rationally combined with practical methods, showing, repeating and checking the volume of memorizing the content and sequence of exercises, understanding their place and role in the student's day regimen ... First, methods and techniques of explanation are applied, then exercises are demonstrated, and at the end instructions aimed at conducting independent studies [10, pp. 43-47; 11; 12, pp. 181-184; 13].

The upbringing of students' interest in physical education is the subject of special attention both in the theory of pedagogy and in the methodology of physical education. This is due to 
the fact that in adolescence, schoolchildren undergo a transition from a natural need for movement to a conscious need for physical exercise. Such an approach, as you know, requires strong-willed efforts of students, which in adolescence are not yet sufficiently formed. Therefore, in practical work, it is necessary to rely on interest, which is a great driving force, can significantly enhance motives and attract schoolchildren to regular physical exercises [14, pp. 155-159; 15].

The mastery of the educational material, the development and upbringing of the personality in the process of teaching motor actions occurs only with the manifestation of its activity in the educational and cognitive activity. Organized activities, in which a person participates without desire, practically does not develop it. In any case, it is important that a clear personal motive for physical education lessons was formulated and a steady interest in them developed [16, pp. 56-62].

Interest is a constant effort of the student's energy, that is, it can facilitate the performance of the activity (when he is interested, he does not need to force himself to strain), or, conversely, stimulates volitional effort, helps to show patience, perseverance, perseverance, and supports purposefulness.

\section{RESULTS}

The formation of interest in physical education is based on the principle of building the pedagogical process of consciousness and activity of students. The essence of this principle is as follows: if a student understands the essence of the task and is interested in solving it, then this speeds up the learning process.

Based on the studied sources, it is possible to systematize the development of interest in playing sports as follows:

1. Interest in knowledge. Its essence is based on obtaining satisfaction of the very process of mastering the whole body of knowledge, abilities and skills of certain types of physical exercises in physical education classes.

2. Cognitive interests are divided into the following levels: lower (an elementary level of cognitive interest, which is determined by attention to specific facts, knowledge, descriptions, actions according to the model; medium (interest in addictions, causal relationships, to their independent establishment); higher level (manifested in interest in theoretical problems in creative activity with the aim of assimilating knowledge).

1. To develop interest in physical education classes, the following methods are used:

1. Exciting learning: the novelty of the teaching material; the use of vivid examples and facts in the process of presenting new material, historicism, demonstration of the practical application of knowledge in connection with the life plans and orientations of students, etc.

2. Use of new and non-traditional forms of education: problem-based learning; heuristic learning; training with computer support; the use of multimedia systems; use of interactive computer tools, etc.

3. Mutual education: peer review of peers' answers; helping weaker students, etc.

4. Participation in discussions and discussions: defending one's own opinion; posing questions to your comrades and physical education teachers; analysis of personal cognitive and practical actions.

Based on the data of scientists, it is obvious that the development of students' interest in physical culture classes largely depends on the influence on their intellectual (the formation of a system of 
knowledge in schoolchildren about the influence of physical exercises on the development of the body, skills and abilities to independently engage in physical exercises based on the implementation of inter-subject connections of physical cultures with human biology, valeology and other subjects); emotional-volitional (emotional-volitional influence on students, aimed at forming a positive attitude towards classes in children) and motivational (influencing the motivational sphere in order to form positive motives in children for physical selfimprovement through the use of various methods of stimulating and motivating) spheres.

The most important task of a physical education teacher is to interest the student in the subject, as well as to form an idea of his own health. Only when children realize the real possibility of such an impact on their own body, it becomes possible to effectively solve motor problems, which is the content of any educational lesson.

\section{Discussion}

Many experts share the opinion that the lack of pronounced abilities can be compensated by the development of other important professional qualities - hard work, honest and serious attitude to one's duties, systematic and constant work on oneself. The physical education teacher's ability to use a person-centered approach and various methods of stimulation and reward can be primarily directed to students with reduced abilities.

A number of research studies by scientists testify to the complex nature of the influence of conditions and a certain rating of some of them: urban and rural living, which does not generate a significant difference of interests; and the age and gender of students and students have a significant impact on the difference of interests.

The center for general interests of classes in the sports section, classroom teaching, has a significant influence on the development of interests in learning. Scientists established in parallel groups different sides of the general structure of interests, different levels of their maturity, and ascertained different forms of manifestation of interests. If we assume that engaging in a favorite sport is based on sympathy, then we can assume that there is a certain relationship between sympathy, aspiration and the strength of interests of student youth. As a rule, the community of interests gives rise to sympathy among young people for each other, and sympathy in the process of two-way communication causes the approximation of interests. The physical development of boys and girls at different levels of education, as a rule, forms significant differences of interest due to the difference in interaction algorithms.

\section{Conclusion}

Analysis of scientific and methodological literature and the practical experience of scientists indicate that the effectiveness of the school process depends on highly qualified teachers. Not an exception is a specialist in physical culture, which, with the help of the acquired knowledge and experience, implemented in a certain sequence, is able to teach students the skills and abilities from many sports, to form in them an interest in learning, to encourage a healthy lifestyle.

An important condition for the effectiveness of the learning process at physical education lessons is the formation of schoolchildren's motivation for such activities, which are the subject of special attention of teachers.

\section{REFERENCES}

1. Turdimurodov, D. Y. (2021). Preschool period: pedagogical aspect of education of 
will in a child. Current Research Journal of Pedagogics (2767-3278), 2(09), 47-51.

2. Turdimurodov, D. Y. (2021). Testing volitional qualities for students of high schools of secondary school. The American Journal of Social Science and Education Innovations, 3(03), 405-413.

3. Турдимуродов, Д. (2021). Formation and education of will in schoolchildren in the process of physical education lesson. Mental Enlightenment Scientific-Methodological Journal, 2021(02), 64-74.

4. Turdimurodov, D.Y. (2020). Pedagogical factors of external stimulation affecting the volitional efforts of schoolchildren during physical exercises of a different nature. Innovations in pedagogy and psychology, 9 (3). (Турдимуродов, Д. Й. (2020). Педагогические факторы внешней стимуляции влияющие на волевые усилия школьников при физических упражнениях разного характера. Педагогика ва психологияда инновациялар, 9(3).)

5. Turdimurodov, D. Yu. (2021). Features of the manifestation of volitional efforts in the process of external stimulation in schoolchildren of 10-12 years old. Academic research in educational sciences, 2 (4), 1348-1354 (Турдимуродов, Д. Ю. (2021). Особенности проявления волевых усилий в процессе внешней стимуляции у школьников 10-12 лет. Academic research in educational sciences, 2(4), 1348-1354.)

6. Abdullaev, Ya.M. (2012). Development of physical education of the younger generation in lifelong education. Young Scientist, (11), 381-383. (Абдуллаев, Я. М. (2012). Развитие физического воспитания подрастающего поколения в непрерывном образовании. Молодой ученый, (11), 381-383.)

7. Abdullaev, Ya.M., \& Yuldashevich, T. D. (2020). Creation of pedagogical conditions in the formation of volitional grades in primary school students. In Colloquiumjournal (No. 24 (76)). Holopristansky regional center of employment. (Абдуллаев, Я. М., \& Юлдашевич, Т. Д. (2020). Создание педагогических условий в формировании волевых качеств у учеников начальных классов. In Colloquium-journal (No. 24 (76)). Голопристанський міськрайонний центр зайнятості.)

8. Turdimurodov, D. Y. (2021). Possibilities of means of physical education in formation of volitional qualities of pupils. Innovations in pedagogy and psychology, 4 (7). (Турдимуродов, Д. Й. (2021). Ўкувчиларнинг иродавий сифатларини шакллантиришда жисмоний тарбия воситаларининг имкониятлари. Инновации в педагогике и психологии, 4(7).)

9. Abdullaev, Y. (2021). Forms and methods of developing the use of folk movement games in high school students. Mental Enlightenment Scientific-Methodological Journal, 2021(2), 73-79.

10. Norboyev N. N. (2020) The most ancient chess in the world detected in uzbekistan //Theoretical \& Applied Science. №. 10. pp. 43-47.

11. Alikulovich, M. K., \& Yuldashevich, T. D. (2020). Development of physical training skills and formation of willpower qualities in extracurricular activities. European Journal of Research and Reflection in Educational Sciences Vol, 8(3)

12. Norboev, N. N. (2019). Physical training methods for orienteering athletes. Questions of Pedagogy, (12-1), 181-184. (Норбоев, Н. 
CURRENT RESEARCH JOURNAL OF PEDAGOGICS 2(10): 247-252

October 2021 DOI: https://doi.org/10.37547/pedagogics-crjp-02-10-44

ISSN 2767-3278

(C)2021 Master Journals

Crossref doi) google

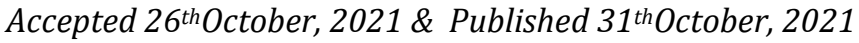

$\begin{array}{llll}\text { H. (2019). } & \text { Методы } & \begin{array}{r}\text { физической } \\ \text { подготовменов- }\end{array} & (9 \text { (94)), 56-62.) }\end{array}$

ориентировщиков. Вопросы педагогики, (12-1), 181-184.)

13. Narzikulovich, N. N. (2020). The effectiveness of doing sport in everyday life. Innovations in pedagogy and psychology, 12(3).

14. Utkir Salimov (2021). Analysis of the attitude of students of the Surkhandarya region to a healthy lifestyle and physical activity. Society and Innovation, 2 (3 / S), 155-159. doi: 10.47689 / 2181-1415-vol2iss3 / S-pp155-159 (Уткир Салимов (2021). Анализ отношения студентов Сурхандарьинской области к здоровому образу жизни и физической активности. Общество и инновации, 2 (3/S), 155-159. doi: $\quad 10.47689 / 2181-1415-v o l 2-i s s 3 / S-$ pp155-159)

15. Menglikulov, Kh.A. (2020). Features of physical training of physical culture specialists in a higher educational institution. Innovations in pedagogy and psychology, 11 (3). (Менгликулов, Х. А. (2020). Особенности физической подготовки специалистов физической культуры в высшем учебном заведении. Педагогика ва психологияда инновациялар, 11(3).)

16. Abdullaev Yashnarjon Mahkamjonovich, \& Turdimurodov Dilmurod Yuldashevich (2020). Development of volitional qualities in adolescents through the means of physical education. (Modern Education (Uzbekistan). (9 (94)), - pp. 56-62. (Абдуллаев Яшнаржон Махкамжонович, \& Турдимуродов Дилмурод Йўлдошевич (2020). Ўсмир ёшдаги ўқувчиларда иродавий сифатларни жисмоний тарбия воситалари орқали ривожлантириш. (Современное образование (Узбекистан). 